\title{
Predictive Factors Associated with Solar Energy Development in Laikipia District Central Kenya
}

\author{
Oscar Wambuguh 1 \\ Environmental Health Sciences \\ California State University, East Bay \\ 25800 Carlos Bee Blvd., Hayward 94542, CA, USA
}

\begin{abstract}
The abundance of sunlight and the availability affordable solar technologies in many areas far from grid-based electricity has sparked the development of renewable energy technologies (RETs) which tap solar radiation energy to provide electricity. A study on solar photovoltaics (SPVs) use and utilization took place in the Wiyumiririe Location of Kenya. A purposive randomized convenience sample of 246 households was selected and landowner interviews conducted guided by a questionnaire, followed by field surveys and observations. Although solar energy contributed less than a quarter of total household energy needs, residents specifically associated it with specific developmental initiatives. Correlation and logistic regression model analyses showed that solar power development was closely associated (and thus can be predicted) from five main independent variables. The findings of the study allowed the development of a probabilistic model general enough to be applicable elsewhere in the development of alternative energy resources particularly those based on solar input.
\end{abstract}

Keywords: SPV, solar panel, RET, predictive factors, logistic regression, solar development

Article History: Received June 12, 2015; Received in revised form August 15, 2015; Accepted October 5, 2015; Available online How to Cite This Article: Wambuguh, O. (2015) Predictive Factors Associated with Solar Energy Development in Laikipia District, Central Kenya. Int. Journal of Renewable Energy Development, 4(3), 197-204.

http://dx.doi.org/10.14710/ijred.4.3.197-204

\section{Introduction}

With the increasing costs of petroleum-based sources of energy and the environmental costs of exploration, extraction, processing, transportation and storage, the development of renewable energy technologies is now not only a green energy alternative, but a necessity (Bhutto et al. 2011; Kumar et al. 2015; Ohunakin et al. 2011. Unfortunately, in many world nations, the development of cleaner alternatives have been hampered by a number of factors including: 1) the high costs associated with them especially solar, nuclear, hydrogen-based sources, wind, geothermal, hydropower and sea-based alternatives (waves and thermal gradients); 2) lack of adequate investment in research and development from government and nongovernmental sources; 3) government subsidies and availability of cheaper grid-based alternatives; 4) total lack of or inadequate government promotions and incentives to citizens who choose to adopt cleaner alternatives; and, 5) lack of knowledge and education for most citizens on the benefits of greener alternatives.

*Corresponding author: 510-885-3252 (Phone)

Email: oscar.wambuguh@csueastbay.edu
The emergence of a market-based solar PV technology in many rural areas of Africa has been cited as resulting from a decline in donor-funded rural electrification infrastructure that dominated energy development in the period before the late1980s. In those days, centralized solar panel stations relying on a large array of photovoltaics were built at costs of between US\$200,000-300,000 but later proved unreliable and expensive to maintain (Green 2000). Starting from the late 1980s and 1990s energy developmental attention focused on economic liberalization and market-based approaches that greatly fuelled and expanded private sector participation (Abavana 2001); Banks 2003). The development of clean energy in rural communities has also been fuelled by availability of affordable solar technologies from Europe, North America, Canada and China (Tickell 2012; SEI 2007; Martinot 2001; Gustavsson \& Ellegård 2002). With the availability of credit facilities in some areas, a clean energy technology has become a viable choice for many rural landowners. Although still very 
Citation: Wambuguh, O. (2015) Predictive Factors Associated with Solar Energy Development in Laikipia District, Central Kenya. Int. Journal of Renewable Energy Development,4(3), 197-204, http://dx.doi.org/10.14710/ijred.4.3.197-204

P a g e $\mid 198$

poorly developed, small-scale, and inefficient, these solar technologies have afforded many rural people access to resources that are freely enjoyed by those who live in urban areas. These include access to opportunities like charging a cell-phone, radio and television and household lighting. Despite the many challenges rural people endure in developing solar technology including equipment costs, reliability, durability, maintenance and expansion, solar energy development has continued. As nations continue to explore and expand clean energy today, it will take the creative forces of ingenuity, entrepreneurship, risktaking, persistence and the market to saw the seeds of an energy infrastructure that will take a long time to build (Arvidson et al. 1999; Shanmugavalli \& Vedamuthu 2015).

With our world population doubled over the last half-century, and our global economy expanding sevenfold, our demands on the earth have become excessive creating a global bubble economy that is bound to burst and cause untold economic decline and human suffer (Hardaway 2014). Keeping the bubble from bursting calls for urgent reordering of priorities and a restructuring of the global economy (Cabraal \& Cosgrove-Davies 1999). This will require an unprecedented degree of international cooperation to stabilize population, climate, water tables and soils at war-time speed. While this urgency may not be visualized so readily by many people, and even though progress will not be swift, there are many signs of hope developing simultaneously in many parts of the world (Cabraal et al. 1996; Hardaway 2014; Odegard \& van der Voet 2014).

According to Acker and Kammen (1996) renewable energy sources made their first real entry to the international scene in 1970s when the two worldwide oil crises occurred. Discussions about RETs have occurred in many international forums including UN Conference on the Environment in Nairobi in 1981, in Rio de Janeiro in 1992 and in the World Summit on Sustainable Development in Johannesburg in 2002. As a result, the development of RETs has increasingly received much attention in developing nations by host governments, multi-lateral donors, non-governmental organizations and increasingly often, by individual consumers (Abavana 2001; Weggoro 2006). In terms of energy use cooking, heating and lighting are by far the highest consumers of energy in developing countries (Barnett 1995; Bokalders 1994; IEA 2002; Leach 2001). There is also a major distinction between energy types used in both urban and rural areas in many developing nations. While those living in major urban centres primarily rely on grid-based electricity, petroleum products like kerosene and liquefied petroleum gas (LPG) and to a lesser extent bio-fuels like charcoal and wood; most rural dwellers primary sources of energy are bio-fuels (wood, charcoal, crop residues, and saw dust) and petroleum products (kerosene and to lesser extent LPG). However, Leach (2001) and Christensen (2001) found out that urban-rural energy source differences were not as discrete, reflecting a continuum such that smaller to mid-sized towns depended more on bio-fuels than larger ones. The study also found a difference in energy source choice between the rich and the poor particularly in urban settings: the richer urban households had more space heating/cooling and lighting with more usage of electrical appliances and more LPG use than rural households that depended more on charcoal and wood (Blaikie et al. 1997; Diarra \& Akuffo 2002).

The study explored solar energy development (hereafter SPV) in Wiyumiririe Location of Laikipia District of north-central Kenya. A major objective of the study was to determine the factors that have contributed to the perceived SPV development success in those small-scale farming communities. The findings of the study allowed the development of a statistical model general enough to be applicable elsewhere in the development of alternative energy resources particularly those based on solar input. The study took place in the Wiyumiririe Location of Laikipia District in north-central Kenya which has previously been described by Wambuguh (2013). The dominant landuse is the district is large-scale ranching (between 50-70\% of district), followed by pastoralism (13\% of the district- more confined in the north and the northeastern parts) and increasingly, by small-scale farming (5-10\% of the district).

\section{Materials and Methods}

The extent of SPV development in the region was obtained through an initial preliminary survey undertaken in the area in consultation with local community leaders, developmental facilitators and small-scale landowners. Due to the random and very localized nature of SPV development in the region, a purposive randomized convenience sample of 246 households (129 with SPV;117 had no SPV) was selected. These were followed by landowner interviews which were guided by a questionnaire and field observations. A logistic regression model that incorporated the predictive factors thought to be important in the successful development of SPV in the region was utilized in data analysis to analyze the importance of factors like socio-economic status, education level, land-parcel size, solar PV maintenance costs, etc.) in the adoption of SPV in this region.

\section{Statistical analysis}

Statistical analysis were performed using SPSS software. First, it was of interest to find the strength of the relationship between SPV development and associated factors like socioeconomic status; solar equipment maintenance costs; presence of salaried household members; whether household owner was a civil servant (or recently retired); size of land parcel; 
permanent house in household (stone/concrete) or semi-permanent (wooden with concrete or nonconcrete foundation); and whether respondent owned or leased the land. To do this, the Spearman's Rank correlation coefficient analysis (Zar 2009) was performed on the data. Coefficients range from 1 negative 1 to positive 1 . The mid-point (zero indicates no correlation, while -1 indicates a strong (negative) inverse correlation. Positive 1 indicates a strong direct correlation.

Second, it was important to find what factors were statistically significant in predicting whether a landowner would develop SPV. To do this the logistic regression model was used. Logistic regression is a variation of ordinary regression, useful when the observed outcome is restricted to two values, which usually represent the occurrence or non-occurrence of some outcome event, (usually coded as 1 or 0 , respectively) (Zar 2009). In this study, there were two outcomes: SPV development (value of 1); and no SPV development (value of 0 ). The model produces a formula that predicts the probability of the occurrence as a function of the independent variable(s), and thus can be used to predict the probability of a hypothetical landowner developing SPV. To do this, logistic regression fits a special $S$-shaped curve by taking the linear regression $(y=a+b X)$, which could produce any $y$-value between minus infinity and plus infinity, and transforming it with the function: $\mathrm{p}=\operatorname{Exp}(y) /(1+\operatorname{Exp}$ $(y))$ often also written as $\mathrm{p}=\mathrm{e}^{\mathrm{a}+\mathrm{bX}} / 1+\mathrm{e}^{\mathrm{a}+\mathrm{bX}}$. Logistic regression also generates the standard errors of estimate and significance levels of a prediction formula and odds ratios (O.R.) associated with each predictor value (with 95\% confidence intervals). The odd of an event is defined as the probability of the outcome event occurring divided by the probability of the event not occurring. The odds ratio for a predictor provides the relative amount by which the odds of the outcome increase (O.R. $>1.0$ ) or decrease (O.R. $<1.0)$ when the value of the predictor value is increased by 1.0 units (Agresti 2007; Hosmer \& Lemeshow 1989). Odds ratios were generated in this study as presented below.

\section{Results and Discussion}

\section{SPV Predictive and Influencing Factors}

A number of conditions were found to be associated (perhaps influencing) the development of solar energy. Among the most important factors was availability of capital, solar equipment maintenance costs, whether landowner was a civil servant or a retired one, presence of salaried grown-up children in household, and land acreage (Fig. 1).

Not unexpected, correlation analysis showed that solar PV development was closely associated with income with a positive Spearman's correlation coefficient
(0.611; Table 1) with solar equipment maintenance costs (coefficient $=0.488$ ); whether a household had grown-up salaried children that supplemented household income (coefficient $=0.331$ ); whether main household decision maker was a civil servant or recently retired (coefficient $=0.328$ ) and land acreage (coefficient $=0.257$ ) (Table 5).

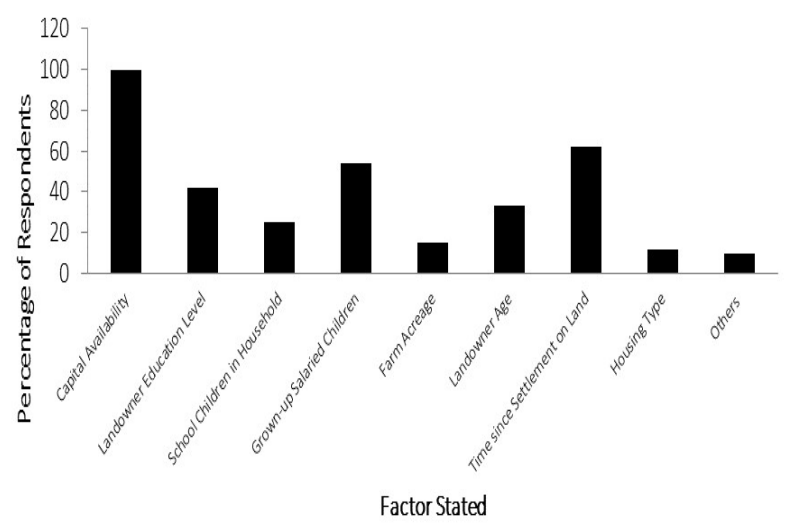

Fig. 1 Predictive Factors Associated with Solar PV Technology in Wiyumiririe Location $(n=129)$

Weak positive correlations were found between solar PV development and whether the main house in household was permanent (stone and concrete) or semi-permanent (wooden with concrete or nonconcrete foundation) (coefficient $=0.178$ ); plus also whether respondent owned or leased the land (coefficient $=0.129$ ).

Table 1

Spearman's Rank correlation coefficients between solar PV development and various predictors

\begin{tabular}{lllllllll}
\hline \multicolumn{7}{c}{ Factor } \\
\hline Factor & INC & CVS & LDS & LCD & HST & CHLD & EQMC & SPV \\
& & & & & & & & \\
\hline INC & 1 & & & & & & & \\
CVS & 0.196 & 1 & & & & & & \\
LDS & 0.195 & 0.12 & 1 & & & & & \\
LCD & -0.119 & 0.052 & 0.058 & 1 & & & & \\
HST & 0.384 & 0.101 & 0.153 & -0.113 & 1 & & & \\
CHLD & 0.353 & 0.144 & 0.154 & -0.055 & 0.15 & 1 & & \\
EQMC & 0.361 & 0.127 & 0.092 & 0.042 & 0.058 & 0.195 & 1 & \\
SPV & 0.611 & 0.328 & 0.257 & 0.129 & 0.178 & 0.331 & 0.488 & 1
\end{tabular}

Legend: INC = Income; CVS = Civil Servant; LDS = Land Size; LCD = Land Condition; HST = Housing

Type; CHLD = Salaried Children; EQMC = Equipment Maintenance Costs; SPV = Solar Power Voltaic

An important objective of this study was to find out the important predictors of solar PV development in this region using the logistic regression model (discussed in "Materials and Methods" above) which generated a log likelihood probability and an odds ratio. 
Citation: Wambuguh, O. (2015) Predictive Factors Associated with Solar Energy Development in Laikipia District, Central Kenya. Int. Journal of Renewable Energy Development,4(3), 197-204, http://dx.doi.org/10.14710/ijred.4.3.197-204

P a g e $\mid 200$

With the data obtained in the study, the results of this statistical analysis are summarised in Table 2.

Table 2

Logistic regression analysis data of solar PV development and its various predictor variables $(117$ cases have $Y=0 ; 129$ cases have $\mathbf{Y = 1 )}$

\begin{tabular}{cll}
\hline Variable & Avg & SD \\
\hline 1 & 0.4919 & 0.4999 \\
2 & 0.7114 & 0.4531 \\
3 & 0.3130 & 0.4637 \\
4 & 0.9106 & 0.2854 \\
5 & 0.2520 & 0.4342 \\
6 & 0.5488 & 0.4976 \\
7 & 0.5244 & 0.5075
\end{tabular}

Overall Model Fit

Chi Square $=168.8367 ; \mathrm{df}=7 ; \mathrm{p}=0.0000$

Intercept -6.1047

Odds ratio and 95\% Confidence Intervals are

\begin{tabular}{cccl}
\hline Variable & O.R. & Low & High \\
\hline 1 & 18.916 & 7.3922 & 48.4088 \\
2 & 5.4501 & 2.1373 & 13.8982 \\
3 & 2.4939 & 1.0882 & 5.7155 \\
4 & 8.9336 & 2.3485 & 33.9834 \\
5 & 0.6683 & 0.2225 & 2.0077 \\
6 & 2.0952 & 0.9580 & 4.5823 \\
7 & 7.3321 & 3.3195 & 16.1952 \\
\hline
\end{tabular}

From these results, the seven predictors of solar PV development in Wiyumiririe (listed as variables on top of Table 2), taken together, yield very significant results (overall logistic model chi-square value = 168.836; $\mathrm{df}=$ $7 ; \mathrm{p}<<0.001$ ). The model also analysed the simultaneous effects of each of these predictors as determinants of solar PV development. The results shown in the middle and lower portion of Table 6 (under coefficients and standard errors; odds ratios and 95\% confidence intervals) indicate that:

- While five of the predictors are important determinants of SPV development, two of them may not be important and can be dropped from the model. First, the housing type (whether permanent or semi-permanent) with a logit of 0.403 and an odds ratio of 0.668 . This means that whether a landowner has a permanent of semi-permanent house type the odds of developing solar energy do not change. Second, the presence of grown-up salaried children supplementing household income with a logit of 0.739 and an odds ratio of 2.095 . This means that solar PV development odds do not increase whether a household has salaried grown-up children supplementing household income or not.
- Of the five other important predictors of solar PV development, annual income seems to be the single most important predictor with a logit of 2.940 and an odds ratio of 18.916. This means the odds of developing solar energy with an average annual income of about US $\$ 600$ increases about 19 times compared to those with lesser annual income. The second most important predictor is whether land is owned or leased with a logit of 2.189 and an odds ratio of 8.934. Land ownership compared to leasing increases the odds of developing solar energy by a factor of 9 . The third most important factor is solar equipment maintenance costs with a logit of 1.992 and an odds ratio of 7.332. If a landowner projects he/she will afford to maintain all purchased solar equipment, this raises the odds of him/her developing solar energy by a factor of 7.3. The fourth most important factor is whether the main household decision maker was a civil servant or recently retired with a logit of 1.696 and an odds ratio of 5.450 . Being a salaried employee (or retired and drawing a pension) increases the odds of developing solar energy by a factor of about 5.5. The final most important predictor of solar development in this region is the size of land in acres with a logit of 0.914 and an odds ratio of 2.494. Having a land size of at least three acres raises a landowner's odds of developing solar about two and half times.

Overall, the results of this model yield a logistic regression equation with the following independent predictor values for solar development in Wiyumiririe:

$\mathrm{SPV}=-6.1047+2.940 \mathrm{INC}+1.696 \mathrm{CVS}+0.914 \mathrm{LDS}+$ 2.189LCD + 1.992 EQMC.

Using this general equation, we can now predict the probability that a hypothetical landowner in Wiyumiririe will develop solar energy. To do this, the yvalue obtained from this equation (SPV value) is then converted into a probability between 0 (as the dependent variable approaches minus infinity) and 1 (as the dependent variable approaches plus infinity) in an S-shaped curve using the function:

$$
\mathrm{p}=\exp (\mathrm{y}) /(1+\exp (\mathrm{y}))
$$

For example, using the general model equation $(\mathrm{y}=$ $6.1047+2.940 \mathrm{X}_{1}+1.696 \mathrm{X}_{2}+0.914 \mathrm{X}_{3}+2.189 \mathrm{X}_{4}+$ $1.992 X_{5}$, Table 2) we can calculate a landowner's $y$ value. We can then calculate the probability of developing SPV by substituting the values in this equation using the general probabilistic function $(\mathrm{p}=$ $\left.\mathrm{e}^{\mathrm{a}+\mathrm{bX}} / 1+\mathrm{e}^{\mathrm{a}+\mathrm{Bx}}\right)$. Substituting the values of $\mathrm{X}_{1}$ to $\mathrm{X}_{5}$ for $\mathrm{a}$ landowner with values of 1 for all $X$ variables $\left(X_{1}\right.$ 
represents income either above US\$600 = value of 1 and below US\$600 = value of $0 ; \mathrm{X}_{2}$ represents land ownership $=1$, and if leased $=0 ; X_{3}$ represents ability to maintain solar equipment $=1$, if unable $=0 ; \mathrm{X}_{4}$ represents being a civil servant or retired $=1$; if not $=0$; and $X_{5}$ represents size of land in acres, if 3 or greater $=1$, and if less than $3=0$ ) gives 3.6263. Using this value in the probabilistic function $\left(\mathrm{p}=\mathrm{e}^{\mathrm{a}+\mathrm{bx}} /\left(1+\mathrm{e}^{\mathrm{a}+\mathrm{Bx}}\right)\right)$ gives $\mathrm{a}$ value of 97.42. The probability of a landowner whose values of variables $\mathrm{X}_{1}$ to $\mathrm{X}_{5}$ are $1 \mathrm{~s}$ (ones) developing SPV in Wiyumiririe is 0.9742 (or $97.42 \%$ ). If the landowner had values of zero for all variables $X_{1}$ to $X_{5}$, the $y$ value from the regression equation above would give a value of -6.1047 . This results in a probability of 0.0022 (or $0.22 \%$ ) for this landowner developing SPV. In most situations, landowners are unlikely to score a value of zero for all variables $\mathrm{X}_{1}$ to $\mathrm{X}_{5}$ (there will likely be a mix of ones and zeros) raising the probability of developing SPV. For instance, a landowner may not own the land they live on (value of zero), or and their land parcel is less than 3 acres (value of zero); but may have been a civil servant/retired (value of 1), has an annual income of at least US\$600 (value of 1), and can maintain solar equipment (value of 1 ). The probability of such a landowner developing SPV is calculated to be 0.6279 (or 62.79\%). In summary, this model has clearly highlighted the five most important factors in solar energy development in the Wiyumiririe region of Laikipia District. By reducing it to a predictive logistic equation, it is a very practical model that can be applied anywhere where the objective is to find out the probability that a given landowner in the community will be able to adopt and develop solar energy for household use.

\section{SPV Current and Future Challenges}

Residents highlighted several factors that were influential in their decision to install SPV (Fig. 2).

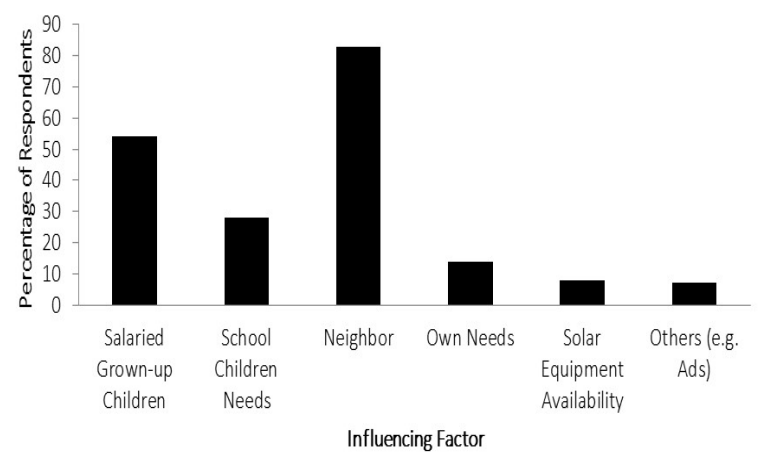

Fig. 2 Percentage of Landowners Influenced by various factors to install Solar PV in Wiyumiririe Location $(n=129)$

Influence from neighbors was the top stated reason $(82 \%)$ followed by presence of salaried family members in the household (54\%). As both Mehlwana
(2002, for solar installations in South Africa), and Ohunakin et al. (2014) (for Nigeria), the low demand, dispersed settlement nature of rural households and fixed costs of grid extension makes it unrealistic that the grid-based electricity will reach most rural communities in the short term.

Recognizing this undisputed fact, a number of multinational donors, private investors and the governments have assisted in rural development of energy based on solar input. However, Mehlwana notes in South Africa, only about $47 \%$ of the rural people seemed happy with the solar systems attributed to "lack of development of upgraded local leadership, culture of enterprise and innovative action and enhanced capacity for people to act in concert purposively and effectively so as to cope with threats and opportunities they face". (Mehlwana 2002; Gustavsson 2002).

The most notable challenges in the future development of SPV in this region are also noted in other areas (Bhutto et al. 2011; Ohunakin et al. 2014; Openshaw 2010; Tickell 2012) were identified by respondents in three main categories: 1) Capital (initial and expansion); 2) Solar energy (amount generated, its use and household dynamics, e.g. presence of energy consuming children/visitors, seasonal solar intensity variation) and; 3) Equipment (maintenance costs esp. batteries and security) and the age and capacity of the solar panel (Fig. 3).

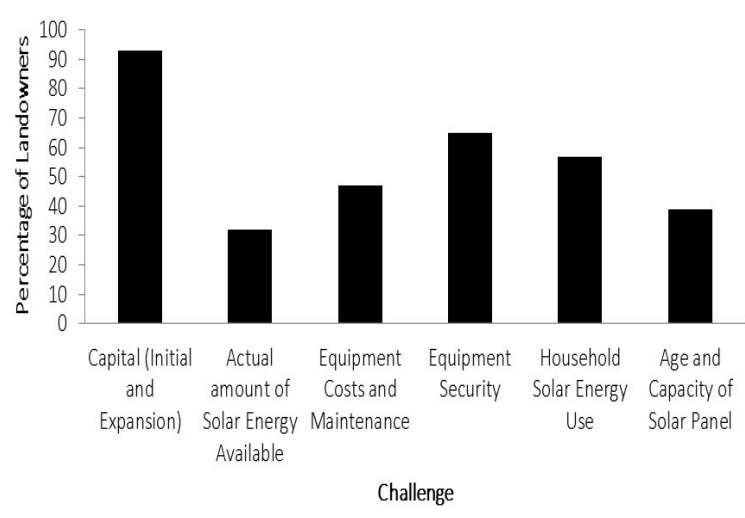

Fig. 3 Solar PV Challenges Landowners Face in Wiyumiririe Location ( $\mathrm{n}=129$ )

Availability of capital will continue to be a big challenge in this community for a long time as their sources of income are agrarian-based, expand slowly and are highly dependent on the regional climate (Saghil 2002). The amount of solar energy generated is dependent on panel capacity which on average is very low for most households and therefore not adequate for their solar energy needs as discussed in Wambuguh (2013). How the amount generated is used is a contentious issue especially during holidays when most household members are home. While younger family members prefer to have radio and TV entertainment 
Citation: Wambuguh, O. (2015) Predictive Factors Associated with Solar Energy Development in Laikipia District, Central Kenya. Int. Journal of Renewable Energy Development,4(3), 197-204, http://dx.doi.org/10.14710/ijred.4.3.197-204

P a g e $\mid 202$

most of the day and evening and at the same time use and charge their cell phones, older members prefer to save solar energy during the day for use in lighting, radio and $\mathrm{TV}$ viewing and cell phone charging in the evenings. It is therefore no surprise that up to $57 \%$ of respondents mentioned this as a constant challenge albeit for only short holiday durations.

Although Wiyumiririe is located right at the equator, solar insulation reaching the surface varies year-around. The highest and most effective solar intensities are available between January and late March followed by lower intensities during the long rains in April/May. Starting from late June to late August, most days are overcast with some days in late July/early August so misty that most households barely capture enough solar energy even to charge cell phones. From September to December most days are sunny but the coming of the more reliable short rains in this area in late October/November with its associated rain clouds greatly reduces effective solar insulation. However, data from this study shows this was considered a serious challenge by only a third (32\%) of the households with SPV, and this is because even when overcast solar panels were able to capture enough energy to power uses like cell phone and flashlight charging.

Almost half of the respondents (47\%) mentioned equipment costs and maintenance continues to be a challenge. Equipment costs add up and as long as household incomes are expanding slowly and the solar PV technology improving, this challenge will remain continue in future (Bhutto et al. 2011; Ellegard \& Nordstrom 2001; Horlocks 2003; Gustavsson 2003; Ohunakin et al. 2014). In fact, 39\% of respondents stated the change in future solar technology remains a big challenge because newer solar panels and storage batteries will be more efficient, of better quality therefore lasting longer and will be much cheaper. Although solar panel maintenance costs are minimal, storage batteries (a good quality one) have a useful life of 4-5 years at the most only requiring annual upkeep. A problem with no easy solution that has to be borne in all households is battery charging during the overcast season. Battery power levels get too low after consecutive days of partial charging to a minimum threshold when they will need boosting from a gridconnected battery charger (Wade 1997). At this point landowners have to hassle with public transport to local trading centres.

The security of solar equipment especially the panel and storage battery is crucial in this area with $65 \%$ of the respondents stating it as a challenge (Fig. 2). Many solar panels are safely secured on main house roof-tops with timber and chicken wire which makes it difficult for would-be burglars to remove. Batteries are usually safely stored inside the main house. Despite this, many respondents stated they cannot leave their households unattended for any extended length of time. Many petty criminals are school drop-outs in the neighbourhood, mostly living with their parents and depend on them for upkeep and sustenance. They do not have any reliable source of income and the small farm acreages owned by their parents complicates any dependable income generating opportunities from crop or livestock farming. They are often caught in their acts and tried, but being petty criminals are often given short sentences that see them return to their communities before long. Many respondents interviewed have come to accept their continued existence as an inevitable societal outcome that has to be tolerated, but requiring careful household mitigative planning.

\section{Conclusion}

To invigorate broad-based rural development policies and activities in communities such as Wiyumiririe, focus needs to be expanded on building the capital base for rural landowners (through savings and credit facilities, non-profit financial assistance, small rural credit extension facilities, and government assistance); providing credit opportunities for local residents to own and expand their land holdings; mobilization of local bottoms-up community-based institutions, and donor funding approaches aimed at developing local potential in rural environments. Despite challenges like sustained capital generation, technological skills, market fluctuations and raw material availability, unpredictable political environments, high rural-urban turnover rates, constantly improving solar technologies, and individual initiatives, rural communities in developing nations worldwide continue to develop energy alternatives to spur their own growth and development. As highlighted by the logistic regression model, available disposable capital, land ownership, and education appear to play a very critical role in solar energy development. As solutions to capital building will not solely rely on subsidies or individual farmer inputs, opportunities need to be found to mobilize tested tools for success including sustainable capital generation, building local institutions and capacities that integrate rural people, local participation in rural development activities and public education and training.

\section{References}

Acker, R. H. \& D. M. Kammen. (1996). The Quiet (energy) Revolution: Analysing the Dissemination of Photovoltaics Power Systems in Kenya. Energy Policy, 24(1), 81-11.

Abavana, C. G. (2001). The Ghana Renewable Energy Services Project. Experience with PV systems in Africa. UNEP Collaborating Centre on Energy and Environment, 52-55. Roskilde, Denmark,

Abavana, C. G. (2000). Renewable energy for rural electrification, The Ghana initiative. Seminar on Rural Energy Provision in Africa, Nairobi, Kenya.

Arvidson, A., S. Kartha, M. Lazarus, G. McGranahan, M. Molares, \& S. de Vylder. (1999). Energy Interventions and Poverty Alleviation. Stockholm Environmental Institute, Stockholm, Sweden. 
Agresti, A. (2007). An Introduction to Categorical Data Analysis (2 ${ }^{\text {nd }}$ ed.). Hoboken, New Jersey: John Wiley \& Sons.

Banks, D. (2003). Photovoltaic System Delivery to Rural Areas Analysis of selected business models. African Solar PV Workshop: Financing Mechanisms and Business Models, May 27-29, Pretoria, UNDP-GEF.

Barnes, D. F. \& J. Halpern. (2000). Subsidies and Sustainable Rural Energy Services: Can We Create Incentives Without Distorting Markets? Washington DC, USA, UNDP/World Bank Energy Sector Management Assistance Programme: 12.

Barnett, A. (1995). Do Environmentally Imperatives Present Novel Problems and Opportunities for the International Transfer of Technology? United Nations, New York.

Bhutto, A. W., Bazmi, A. A., \& Zahedi, G. (2011). Greener energy: Issues and challenges for Pakistan - Biomass energy prospective. Renewable \& Sustainable Energy Reviews, 15(6), 3207-3219.

Blaikie, P., K. Brown, M. Stocking, L. Tang, P. Dixon \& P. Sillitoe. (1997). Knowledge in Action: Local Knowledge as a Development Resource and Barriers to its Incorporation in Natural Resource Research and Development. Agricultural Systems, 55(2), 217237.

Bokalders, V. (1994). Rural Lighting - A guide for development workers, Intermediate Technology Publications.

Cabraal, A. \& M. Cosgrove-Davies. (1999). Accelerating Sustainable PV Market Development, Asia Alternative Energy Program (ASTAE), The World Bank, Washington, D.C., USA.

Cabraal, A., M. Cosgrove-Davies \& L. Schaeffer. (1996). Best Practices for Photovoltaic Household Electrification Programs: Lessons from Experiences in Selected Countries. Washington, The International Bank for Reconstruction and Development/The World Bank

Christensen, J. M. (2001). Foreword. Experience with PV systems in Africa. UNEP Collaborating Centre on Energy and Environment, Roskilde, Denmark: vi-vii.

Diarra, D. C. \& F. O. Akuffo. (2002). Solar Photovoltaic in Mali: Potential and Constraints. Energy Conversion and Management 43,151-163.

DME (1998). White Paper on the Energy Policy of the Republic of South Africa $1998 . \quad$ Available from: http://www.dme.gov.za/publications/wp ene/whitepaper199 8.htm

Duke, R. D., A. Jacobson \& D. M. Kammen. (2002). Photovoltaic Module Quality in the Kenyan Solar Home Systems Market. Energy Policy 30,477-499.

Ellegård, A., A. Arvidsson, M. Nordström, O. Kalumiana \& C. Mwanza. (2003). Rural People Pay for Solar: Experiences from the Zambia $P V$-ESCO Project. ISES 2003, Göteborg.

Ellegård, A. \& M. Nordström. (2001). Rural Energy Service Companies Experiences from Zambia. Stockholm, Stockholm Environment Institute, SEI: 52.

Ellegård, A., A. Arvidsson, M. Nordström, O. Kalumiana, \& C. Mwanza. (2003). Rural People Pay for Solar: Experiences from the Zambia Pv-Esco Project. Paper presented at the ISES 2003, Gothenburg, Sweden.

Gustavsson, M. \& A. Ellegård. (2002). The impact of solar home systems on rural livelihoods - Experiences from the Nyimba Energy Service Company in Zambia. Renewable Energy (unpublished manuscript).

Green, G. (2000). Power to the People - Sunlight to Electricity Using Solar Cells. Sydney, University of South Wales Press Ltd.

Gustavsson, M. (2002). Solar Home System Survey 2001 - Survey results from Eastern Province Zambia. Gothenburg, Human Ecology Section: 49.

Gustavsson, M. (2003). Nigerian Drama and Studies at Night - Impact of Solar Electric Services on User's Livelihood Systems. Paper presented at the Paper presented on International conference ISES 2003, Gothenburg, Sweden, 14-19 June 2003.

Hardaway, R. (2014). As the world welcomes its seven billionth human: reflections and population, law, and the environment. Sustainable Development Law \& Policy, 14(1), 4-61.
Horlocks, C. (2003). Shell-Eskom Solar home systems in South Africa. African Solar PV Workshop: Financing Mechanisms and Business Models, May 27-29, Pretoria, UNDP-GEF.Hosmer, D. W. \& Lemeshow, S. (1989). Applied Logistic Regression, New York, NY: John Wiley \& Sons.

International Energy Agency (IEA), (2002). Financing Mechanisms for Solar Home Systems in Developing Countries - The Role of Financing in the Dissemination Process, International Energy Agency Implementing Agreement on Photovoltaic Power Systems: 104

Kalumiana, O. (2002). Rural Energy Access: Promoting Solar Home Systems in Rural Areas in Zambia - a Case Study. Paper presented at the WREC, Köln, Germany, 29 June - 5 July.

Khennas, S. (2002). Energy Services and Sustainable Development: a Multi-level Approach. Renewable Energy for Development 15(1/2), 12. Stockholm Environmental Institute, Stockholm, Sweden.

Kjellström, B. (2005). Renewable Energy Technologies for Decentralised Rural Electricity Services. Renewable Energy for Development 18(1), 3-5.

Kjellström, B., M. Katyega, D. Noppen, \& A. Mvungi. (1992). Rural Electrification in Tanzania: Past Experiences - New Approaches. Stockholm Environmental Institute, Stockholm, Sweden.

Kjellström, B., A. Arvidson, H. Forslund, \& I. Martinac, I. (2005). Report from an International Workshop held in Studsvik, Sweden 10-12 June 2004. SEI Climate and Energy Programme, Stockholm, Sweden.

Kumar, A. Baredar, P., \& Qureshi, U. (2015). Historical and recent development of photovoltaic thermal (PVT) technologies. Renewable \& Sustainable Energy Reviews, 42, 1428-1436.

Leach, G. (2001). Village Power 2000 - PVs against Poverty? Renewable Energy for Development, 14(1), 4-5. Stockholm Environmental Institute, Stockholm, Sweden.

Martinot, E. (2001). Renewable Energy Investment by the World Bank. Energy Policy, 29, 689-699.

Mbumwae, V. (1998). National Stakeholders' workshop on renewable energy in Zambia. Held on June 23, 1998, Intercontinental Hotel, Lusaka, Zambia.

Melwana, M. (2002). Strategies for a Sustainable Future: A Decade of Rural Electrification in South Africa (1991-2000). Renewable Energy for Development, 15(1/2), 1-3. Stockholm Environmental Institute, Stockholm, Sweden.

Mokhutsoane, L. (2001). Lesotho's experience with PV systems. Experience with PV systems in Africa. UNEP Collaborating Centre on Energy and Environment: 23-26, Roskilde, Denmark,

.Morales, M. M. (2002). South African Women on Water, Energy and Food. Renewable Energy for Development 15(1/2), 6-7. Stockholm Environmental Institute, Stockholm, Sweden.

Mulugetta, Y. \& T. Nhete. (2000). Photovoltaics in Zimbabwe: Lessons from the GEF Solar Project. Energy Policy 28, 1069-1080.

Nordstrom, M. (2005). The Bemused Observer - An Interview with Gerald Leach. Renewable Energy for Development 18(1):1-2. Stockholm Environmental Institute, Stockholm, Sweden.

Odegard, I.Y.R. \& van der Voet, E. (2014). The future of food Scenarios and the effect on natural resource use in agriculture in 2050. Ecological Economics, 97, 51-59.

Ohunakin, O. S., Adaramola, M. S., Oyewola, O. M., \& Fagbenle, R. 0. (2014). Solar energy applications and development in Nigeria: Drivers and barriers. Renewable \& Sustainable Energy Reviews. 32, 94-301.

Openshaw, K. (2010). Renewable energy and development. Journal of Tropical Forest Science, 22(1), preceding p1-1.

Saghil, J. (2002). The Role of Energy in Sustainable Development. Renewable Energy for Development 15(1/2), 10-11. Stockholm Environmental Institute, Stockholm, Sweden.

Shanmugavalli, K. R. \& Vedamuthu, R. (2015). Viability of solar rooftop photovoltaic systems in group housing schemes. Current Science, 108(6), 1080-1085.

Solar Energy International (SEI). (2007). Renewable Energy Education Program. Carbondale, Colorado.

SPSS Software (IBM). (2015). Information available at http://www01.ibm.com/software/analytics/spss/ 
Citation: Wambuguh, O. (2015) Predictive Factors Associated with Solar Energy Development in Laikipia District, Central Kenya. Int. Journal of Renewable Energy Development,4(3), 197-204, http://dx.doi.org/10.14710/ijred.4.3.197-204

P a g e 1204

Stone, L. (1997). Solar Baking under the Sonoran Sun. Home Power, 59, $1-4$.

Tickell, O. (2012). Renewable revolution. Resurgence \& Ecologist, 273, 13-15.

Wade, H. (1997). Solar Photovoltaics for Rural Electrification - What Happened to the Promises? Renewable Energy for Development 10(1), 4-6.

Wambuguh, O. (2013). A Review of a Successful Unsubsidized MarketBased Rural Solar Development Initiative in Laikipia District, Central Kenya. International Journal of Renewable Energy Development, 2(3), 151-164.

Weggoro, N. C. (2006). East African Community Secretariat, Arusha, Tanzania Renewable Energy for Development 19(2), 11.

Zar, J. H. (2009). Biostatistical Analysis (5 ${ }^{\text {th }}$ ed.). New York, NY: Pearson Publishers. 